\title{
From Scar Trees to a 'Bouquet of Words': Aboriginal Text is Everywhere
}

\section{Crystal McKinnon}

I remember once, many years ago, walking along Grattan Street in Carlton towards the Koori Student Liaison Unit in Bouverie Street with Ngarrindjeri student Fiona Rigney and Wiradjuri man Michael Penrith. Michael remarked, 'You know, our people, our culture, are all around us and underneath us and beside us. We are walking across their bones, on our culture, our history.' These words have stayed with me ever since. Particularly when I am walking along that same sidewalk, they come back to me and bring the past crushingly into the present. I am reminded of how Aboriginal people have marked the landscape for tens of thousands of years. Our textual productions cover outback deserts and country towns, and remain throughout urban cities and suburban sprawl. Though some may 'walk across' these productions without realising they are there, they are present nonetheless - the right person, a knowledgeable reader, recognises these signs of the past in the present and sees links to the past in contemporary markings. The scar trees that dot the sides of the road, the shell middens that are along the coastlines, the graffiti that declares 'I am Aboriginal' with a Koori flag sketched beneath, and the sounds of the didgeridoo busker are all textual productions of ours. Aboriginal text is everywhere.

So what is Aboriginal textual production? In thinking broadly here about what an 'Aboriginal text' is, I take the lead from many Aboriginal artists and musicians who declare that what makes their creative works 'Aboriginal' is that an Aboriginal person created it. Expanding this notion, an 
Aboriginal text is then something that an Aboriginal person produces, whether that be a Gunditjmara singer-songwriter performing her song on stage at the Adelaide Festival, or a Wathaurong woman who weaves a basket from native grasses. When a text is created, the person necessarily brings with them their identity as an Aboriginal person, which cannot be removed from the text produced in this process - an integral characteristic of the text that can be available to the right reader. In this way, too, these textual productions are also cultural productions. Embedded within these texts are Aboriginal traditions, knowledges, identities and culture. They reveal many markers of Aboriginality, such as perspectives on history, social organisation and kinship structures, spiritual beliefs, associations with land and country, and lived experiences. They tell a story and in so doing they contain the legacy of our experiences.

Some texts are produced with an intended audience. Aboriginal authors, playwrights, singer-songwriters and poets all create texts with the intent of it being received, being read. Some do this with the explicit motivation of inserting their own identities, experiences and understandings of Aboriginality into a public discourse. As Stephen Muecke reminds us, in the colonial encounter 'those who can't speak "die".' ${ }^{1}$ Recalling Jack Davis speaking in 1983 at the launch of his book of plays, Kullark/The Dreamers, Cliff Watego writes that Davis 'spoke of how in the 1960 s there was a consensus among leading black activists to enlighten the white public to the grievances and aims of black Australians through literature'. ${ }^{2}$ Davis explained:

We used to speak in those days when we were talking about politics - black politics - of how we were going to make ourselves within the white Australian society. And even in those days when we went back to our little dingy rooms, we said (referring to, among others, Kath Walker, Faith Bandler, and Ken Colbung), 'Well we've got to write about this, we've got to tell the people'. ${ }^{3}$

Mandawuy Yunupingu of Yothu Yindi echoes Davis' words when he describes how '[a]ll of my songs are focused on how 
we live - the times when white people took our freedom. I want my music to give others an understanding of Aboriginal life and an idea of where we're coming from.' Lionel Fogarty likewise tells us:

I want to give everybody my understanding so that they can understand what the reality is in my community; the dreaming and the need for revival of my language and connection to the land. When people read my poetry I want them to feel the spirit that is in me and in the people of my community. ${ }^{5}$

These types of intentional textual creations by Aboriginal people have produced what Marcia Langton has described as a 'theatre of politics' in which sophisticated representations of Aboriginality can circulate. ' 'We must continually subvert the hegemony over our own representations,' Michael Dodson argues, 'and allow our visions to create the world of meaning which we relate to ourselves, to each other, and to non-Indigenous peoples'. 7 This type of deliberate creation by Aboriginal people of text forms one part of the discourse Langton identified; they are easily recognised, and read, as representations of Aboriginal people and communities.

The production of some texts though is not always accompanied with the explicit purpose of making a text. They are not necessarily deliberate representational productions but are representational nonetheless. The unintentional text may be thought of as a production which is derived from the practicing of culture, a lived expression of being Aboriginal. Taken together, intentional and unintentional texts offer deeper understanding of not only the complexity of Aboriginal representation and identities but of all aspects related to Aboriginal people and communities. Shell middens or scar trees - these types of textual productions are not necessarily produced as texts to be read by an audience, but they have become available for readings today.

Many of the critical engagements by scholars with Aboriginal textual and creative production begin their discussion in the mid twentieth century. This is not without reason. In the 1960 s vibrant Aboriginal literature, poetry, 
contemporary art and music scene began to emerge. This bourgeoning movement of Aboriginal textual production gained momentum and magnitude throughout the $1970 \mathrm{~s}$ and 1980 s as more and more works emerged and were circulated. Many major events in Australian history ushered in and facilitated this period of artistic textual growth. Some well-known moments include the 1967 Referendum, the 1965 Freedom Rides throughout New South Wales led by Charlie Perkins, and the establishment of the Aboriginal Tent Embassy at Parliament House in Canberra in 1972. Two works in particular are seen as marking the beginning of this new era of Aboriginal textual production. In 1964 Oodgeroo Noonuccal published her widely acclaimed and popular collection of poetry, We Are Going, which was closely followed by Mudrooroo's novel Wild Cat Falling in $1965 .{ }^{8}$ Thus, the scholarship dealing with Aboriginal texts has often begun here. Jack Davis' poem 'Need' captured the importance of the written word and poetry for these newly emerged Aboriginal writers:

I need a bouquet of words today

To bind my heart in interplay

To strengthen my will

to grind to grist

to lighten the dark

and the shrouded mist

to remove the mask

unclench the fist

To better the world

for tomorrow ${ }^{9}$

Davis's prose, showing the importance of words to him, would likely ring true for other Aboriginal people creating textual productions using words and language. Though the importance of this cultural renaissance in the 1960 s and beyond cannot be underestimated, Aboriginal people have used language and words to create text in the form of story, literature, music, letter writing and poetry well before this era. Some research certainly examines these types of textual 
productions of Aboriginal people in early colonial encounters, long before these twentieth-century developments. This includes the work of Ian Anderson, Michele Grossman, Mudrooroo Narogin, Anita Heiss and Peter Minter, and Penny van Toorn, whose essay is included in this collection. ${ }^{10}$ Their scholarship has shown how, as Anderson states, the often used catch-cry of postcolonial studies that "the empire writes back" would more accurately read: "the empire has already written back"'. ${ }^{11}$

Examining Aboriginal writing from Lake Condah, van Toorn uses the theories developed by political scientist James C. Scott regarding 'public and hidden transcripts' - 'that which can safely be said publicly and that which must remain concealed' - to place these writings within a framework of resistance. ${ }^{12}$ Van Toorn examines life for Aboriginal people living on Lake Condah Mission Station in southwestern Victoria, challenging the notion of Aboriginal people's passivity, powerlessness and cooperation under conditions of colonial control. She tells us how the public transcript, those generated by reserve and mission managers and other government officials, were 'discursive performances that affirmed, naturalised and justified their power over Aboriginal people'. ${ }^{13}$ Van Toorn dismantles this hegemony as she persuasively makes the case that Aboriginal people, at Lake Condah mission and beyond, feigned consent towards authorities, engaging in strategic performances, and often using a kind of doublespeak to express their dissatisfaction. Hidden transcripts, secreted in texts, formed a major response by Aboriginal people who were to a large extent unable to express explicit opposition to their situation for fear of punishment or retribution. Thus, van Toorn makes an important contribution to our understanding of Aboriginal responses to colonial authorities and broadens the idea of what we consider to be Aboriginal text.

Indeed Aboriginal people have always created texts, both before invasion and after white-settler contact. In widening the scope to understand texts by Aboriginal people as something produced not only throughout colonisation but also before invasion, we expand our understanding of our texts - not only what they are but what they represent and the possibilities they hold. It is not the case that Aboriginal people 
began telling stories and creating texts when white people came to our lands, it is that the vehicle and genre of some of these productions have changed. Some, like literature and contemporary art and music, are more identifiable as texts. But if we consider text to be about story, and to be a product of culture, then Aboriginal people have always told stories and always produced text from culture.

If we limit the frameworks for what is considered to be Aboriginal text by time, marked by contact, we only reinforce hegemonic ideas of colonial power and superiority and Aboriginal subordination and inferiority. We have always explored our place in the world and our interrelationships, through ceremony and art for instance, and have always practiced our culture, created knowledge and held complex philosophical beliefs and spiritual understandings. Texts produced by Aboriginal people, or more accurately by a Wurundjeri person, a Wathaurong person, a Wiradjuri person or in my case an Amangu person, are not dependant upon our relationships with colonisation or contact with white people. Understanding the texts we produce as a part of the practice of being from a sovereign Aboriginal group, not limited by colonial concepts of time, but moving beyond those borders assists us to wrestle the Aboriginal texts from all-encompassing colonial encounters. Broadening our understanding and conceptions of the production of Aboriginal text to those which encompasses time before white contact challenges the understanding of Aboriginal textual production and reframes it as an Aboriginal production not reliant upon settler society. These texts, produced in the present and in the past, are threaded together by stories, and evidence the continuity of Aboriginal lived cultural presence. Our creative work 'expresses the values and aesthetics of our people and connects us to them and to our ancestors and future generations'. ${ }^{14}$ We are connected through texts, to each other and to the past, present and future. These texts are an archipelago of Aboriginal stories, and the stories form the bedrock upon which they are connected, in a continuity that moves beyond the limits of time and place.

In Anne Brewster's interview with Kim Scott, Scott speaks about the concept of story, and its continuity with and 
importance to culture. He states:

In literature - in terms of language and stories - continuity is really important for we Indigenous people because that's the culture, that's spirit. Culture is a manifestation of spirit. That's not an intellectual concept; that's what I feel. ${ }^{15}$

Linking the idea of story as a continuity of culture, Scott is also articulating culture as both a spiritual and an embodied, lived experience for him as a Noongar man, which is inscribed within the textual production of literature. His cultural identity as a Noongar man is crucial to his work and he states that 'In my heart I'm trying to put myself or Noongar culture at the very centre of things. ${ }^{16}$ For Scott, the strength of Noongar culture is intertwined with the survival of Noongar language. He tells of the importance of language loss, and its power when it is reclaimed, stating: 'The idea of being linguistically displaced and dispossessed, even in one's own country; and then language comes back and ones makes oneself an instrument for it and for the spirit of place. ${ }^{17}$ This articulation shows the complexity of the relationship between the dispossession of language, and its function, both temporally and through embodiment, of the creation of place through language reclamation and subsequent linguistic cultural practices.

Like Scott, Kathleen Petyarre also speaks about the importance of reclamation of past cultural practices. Petyarre discusses her paintings included in the exhibition 'Arnkerrth: Kathleen Petyarre, Abie Loy' as part of the 'Body Painting Series'. When Christine Nicholls asks, 'What makes you want to paint these works?' Petyarre responds with 'I've been thinking a lot about those old days and how we used to put that body paint on ourselves. I've been thinking back a lot, how we don't do it now. ${ }^{18}$ A continuity of story and of textual production is evident here in this statement; Petyarre is stating that older cultural practices are the inspiration for the creation of her contemporary art works. Petyarre goes on to describe the ceremony and the painting of women's bodies, telling of the gendered nature of the ceremony-that it is for women only-which is informed by Law. She tells Nicholls: 
This body painting (that is, in Kathleen's recent work) is for women-only ceremony. It's painted on our stomachs and thighs like an apron - in those days (we wore) no pants on our back or front side, just naked, naked backsides. (Laughing) Naked! There's (a) string belt, and underneath was the ochre paint. The ochre paint goes half way up (our bodies) - from knees up to waist. We wore hairstring belts around our middles, with strings hanging down over black, white and mainly yellow ochre paint underneath. This is really Old Law for Anmatyerr dancing ladies, not for men. ${ }^{19}$

Jennifer Biddle and Erin Manning also discuss the contemporary artistic production of Petyarre, along with Emily Kame Kngwarreye and Dorothy Napangardi, in this collection. ${ }^{20}$ In both articles, these authors challenge the readers of the texts produced by these Aboriginal women, and offer a new exploration of the way that their art can be understood. In Biddle's piece, she argues that rather than the dominant interpretation of these women's paintings as representations of maps of 'country' or Dreaming narratives, there is a 'breasted ontology' informing their creation, 'a cultural way of doing and being in the world' which 'literally manifest in the ways in which these paintings are produced and, in turn, are experienced by the viewer'. ${ }^{21}$ Concerned with how these artworks are experienced by viewers outside the communities that women belong to, she argues these works 'engender a bodily relation between viewer and image' and that this relation is 'one in which the viewer relinquishes her sense of separateness from the canvas, where a certain coming-into-being in relation to the painting occurs', ${ }^{22}$ Rather than just receiving, viewing, or reading the text, Biddle sees an 'intercultural encounter' which is experienced both bodily and temporally. Manning likewise sees the relationship between the artistic text and viewer as a type of intercultural encounter where, if the viewer wishes to engage these artworks, then they must recognise and employ alternative methods to begin that engagement. A 'relationscape' is one way she describes this engagement, where artwork 'create[s] a movement of thought, a movement that is marayin, at once painting, song, dance, sacred object and power word'. ${ }^{23}$ 
Manning continues: 'Through their work, we move toward a topological hyperspace of experience, asking once again how emptiness is configured, how topologies extend our worlds, rhythmically (de)forming them, and how maps that senseacross create durations which eventfully alter what experience can be. ${ }^{\prime 24}$ For Manning, the experience of the viewer of the text is an engagement, which requires a reorientation of the viewer's perception from the outset, which then opens up possibilities and creates a 'relationscape'.

Alison Ravenscroft is similarly interested in the relationship between a text and its audience, particularly the white audience. Ravenscroft uses Roberta Sykes's autobiography Snake Dreaming, and its reception by non-Indigenous readers, to probe the question of race and its production in Australia. In particular, she 'consider[s] the ways in which white readers have produced racialised meanings from the text; in particular, how whiteness, blackness and Aboriginality have been read, and by what signifiers'. ${ }^{25}$ She looks at the reading of Sykes's race, alongside the dominant reading by non-Indigenous people of her mother's 'unambiguous whiteness' to 'show the uncertainty and the contingency of racial identities' and that 'those identities are formed in the context of racialised social relations, and that the subject is produced as white or black according to historically shifting signifiers'. ${ }^{26}$ She shows how Sykes's work 'is a text which can be read as destabilising the definitions of whiteness and blackness which have been mobilised by Sykes's white critics; it is a text which offers a critique of the very discourses which these reading practices have reinscribed'. ${ }^{27}$ In Ravenscroft's article, she is harnessing the power of text to challenge hegemonic conceptions of whiteness, blackness and Aboriginality and show the cyclical way that these discourses operate to define, limit and control. At 'the heart of Sykes's autobiography' is what Alexis Wright calls the 'hidden contact', which belies the purity of White Australia 'and suggests the disavowed proximity of Aboriginality in White Australia's history. ${ }^{28}$

Katelyn Barney picks up on Ravenscroft's discussion of the power of discourse and racialisation, but in her essay she examines notions of Aboriginalism and its operation to produce narrow definitions of 'authentic' Aboriginal people 
and cultures. These types of ideas of authenticity plague not only musicians but many Aboriginal people who sit outside these stereotypes. Detailing the way Aboriginalism is constructed in Australia, she engages Aboriginal women musicians' perspectives to show how they 'play around, within, and against such musical constructions by actively negotiating, challenging, and using them while blurring and merging the borders between contemporary and traditional Indigenous musical expression through the use of a wide range of musical styles and instrumentation'. ${ }^{29}$ Barney places herself within the piece, and understands that ' $[\mathrm{w}]$ riting about Indigenous Australian issues, peoples and cultures is inherently political'. ${ }^{30}$ As a non-Indigenous researcher, engaged in research and writing about Indigenous people and communities, she asks ethical questions of herself and the reader. She recognises that she too is engaged in processes which create Aboriginalist discourse, 'despite my intentions, ultimately the work remains my interpretation of their words' but attempts to work within ethical frameworks where ' $[t]$ he best that I can hope for is to incorporate the voices of performers and allow them to speak in their own voices rather than interpreting them through my voice.'. ${ }^{11}$

The last piece in this section is by Richard Martin, and he combines textual analysis and ethnography to discuss three 'explorer trees' and show some of the ways there are struggles over the meaning of exploration, and colonisation, in northern Australia. He argues that utilising ethnographic and textual analyses together helps us go 'beyond simplistically politicised interpretations of these trees into the realm in which nonsymbolic, non-representational meanings are generated and re-generated without end'. ${ }^{22}$ In his article, he is concerned with revealing how text, in the form of the explorer trees, can transform space into place. He argues that the trees generate 'a series of conflicting and overlapping explanations that cannot be reduced to a single or even dual interpretation'.33 Martin is not only concerned with the 'writer' or the 'reader' of the text, but rather emphasises the 'creative representations which make meanings proliferate', critiquing the 'textual tradition of "reading" settler-colonial artifacts'. ${ }^{34}$ In so doing, Martin complicates our understandings of Australian histories 
and identities, and suggests that the trees should be read for 'suggestion of other divergent responses, including new ones, where the meaning of exploration and colonisation is created, and re-created, along with the experience of place'. ${ }^{35}$

Though texts can generate a series of different readings and interpretations, not everything can, or should, be spoken about or critiqued. The idea that all textual productions by Aboriginal people are something that anyone can access and mine for their own purposes is a continuation of colonialAboriginal relations of power and knowing. The questioning of this right, or a refusal to adhere to this persistent aspect of colonial power, is a deeply political act. When Scott expresses reluctance to talk about Noongar culture and spirit, he is refusing the reader access to certain parts of him and his community. Ravenscroft's challenge of the approach of white readers to Sykes's autobiography as a text which will finally tell them for certain Sykes's racial origins, is also a critique of regimes of colonial power. When Nicholls asked Petyarre to comment on her work and its representational aspect about breasts and fertility, Petyarre states that it is 'true'. Nicholls asks, 'Are you able to say more?' and Petyarre replies, 'No. True, it's true, but I won't say more. Not a word. Secret. ${ }^{36}$ Though the text may be out there, all aspects of it are not necessarily, nor should they be, available for reading and interpretation.

The articles gathered in this section of collection all show the desire for a deeper understanding of Aboriginal culture, knowledge, and histories, and turn to text as a way to access these different stories. When text manifests it makes available a whole network of discourses about knowledge, power, history and culture. Understanding Aboriginal text as stories in a broad and interconnected way, without the hindrance of temporal or spatial borders, releases the full possibilities of the power of Aboriginal cultural production. Scott suggests to us that 'Story is layers and interpretations; let's have a think about this and provoke. ${ }^{37}$ This section invites readers to think deeply about the power of Aboriginal text and provokes us to consider the many possibilities found within interpretations of these stories. And there are so many texts to read and stories to be told. As Aboriginal people - as Noongar 


\section{people, as Wiradjuri people, as Eora people - we have always produced texts. Aboriginal text is everywhere.}

\section{Notes}

1 Stephen Muecke, 'The Scribes', Meridian, vol. 4, no. 1, 1985, p. 42.

2 Cliff Watego, 'Backgrounds to Aboriginal Literature', in Emmanuel S. Nelson (ed.), Connections: Essays on Black Literature, Aboriginal Studies Press, Canberra, 1988, pp. 11-23, 11.

3 Jack Davis quoted in Watego, p. 11.

4 Mandawuy Yunipingu in Liz Thomson (ed.), Aboriginal Voices: Contemporary Aboriginal Artists, Writers and Performers, Simon \& Schuster, Sydney, 1990, p. 103.

5 Lionel Fogarty, New and Selected Poems: Munaldjali, Mutuerjaraera, Hyland House, Melbourne, 1995, p. ix.

6 Marcia Langton, 'Aboriginal Art and Film: The Politics of Representation', in Michele Grossman (ed.), Blacklines: Contemporary Critical Writing by Indigenous Australians, Melbourne University Press, Melbourne, 2003, pp. 109-24, 124.

7 Michael Dodson, 'The Wentworth Lecture. The End in the Beginning: $\operatorname{Re}(\mathrm{de})$ fining Aboriginality', Australian Aboriginal Studies, no. 1, 1994, p. 6.

8 Oodgeroo Noonuccal, We Are Going, Jacaranda Press, Brisbane, 1964; Mudrooroo, Wild Cat Falling, Angus \& Robertson, Sydney, 1965.

9 Jack Davis, 'Need', in Black Life: Poems, University of Queensland Press, Brisbane, 1992, p. 7.

10 Ian Anderson, 'Introduction: The Aboriginal Critique of Colonial Knowing', in Michele Grossman (ed.), Blacklines: Contemporary Critical Writing by Indigenous Australians, Melbourne University Press, Melbourne, 2003, pp. 17-24; Michele Grossman, 'When They Write What We Read: Unsettling Indigenous Australian Life-writing', Australian Humanities Review, no. 39-40, September 2006; Mudrooroo Narogin, Writing from the Fringe: A Study of Modern Aboriginal Literature, Hyland House, Melbourne, 1990; Anita Heiss and Peter Minter, 'Aboriginal Literature' in Anita Heiss and Peter Minter (eds), Macquarie Pen Anthology of Aboriginal Literature, Allen \& Unwin, Sydney, 20o8, pp. 1-8; Penny van Toorn, 'Hegemony or Hidden Transcripts? Aboriginal Writings from Lake Condah, 1876-1907', in this volume, pp. 384-407.

11 Anderson, p. 18.

12 Van Toorn, p. 384.

13 Ibid., p. 388.

14 Kateri Akiwenzie-Damm, 'Preface: We Remain, Forever', in Kateri AkiwenzieDamm and Josie Douglas (eds), Skins: Contemporary Indigenous Writing, Jukurrpa Books, Alice Springs, 200o, pp. vi-xi, vi.

15 Anne Brewster and Kim Scott, 'Can You Anchor a Shimmering Nation State via Regional Indigenous Roots? Kim Scott talks to Anne Brewster about That Deadman Dance', Cultural Studies Review, in this volume, p. 518.

16 Ibid., p. 513.

17 Ibid., p. 519.

18 Christine Nicholls, 'Old Lady Mob', in this volume, pp. 450.

19 Ibid.

20 Jennifer Biddle, 'Breasts, Bodies, Art: Central Desert Women's Paintings and the Politics of the Aesthetic Encounter', in this volume, pp. 424-48; Erin Manning, 'Relationscapes: How Contemporary Aboriginal Art Moves Beyond the Map', in 
this volume, pp. 458-78.

21 Biddle, p. 425.

22 Ibid.

23 Manning, p. 475 .

24 Ibid., pp. 475-6.

25 Alison Ravenscroft, 'The Production of Whiteness: Revisiting Roberta Sykes's Snake Dreaming', in this volume, p. 408.

26 Ibid., pp. 415, 409.

27 Ibid., p. 408.

28 Ibid., pp. 421.

29 Katelyn Barney, 'Gendering Aboriginalism: A Performative Gaze on Indigenous Australian Women', in this volume, p. 487.

30 Ibid., p. 493.

31 Ibid., p. 494.

32 Richard Martin, 'Reading' the Landsborough, Leichhardt and Gregory Explorer Trees of Northern Australia in Cultural Studies and Anthropology', in this volume, p. 539 .

33 Ibid., p. 524.

34 Ibid., p. 525.

35 Ibid., p. 540.

36 Nicholls, p. 455.

37 Brewster, p. 234. 